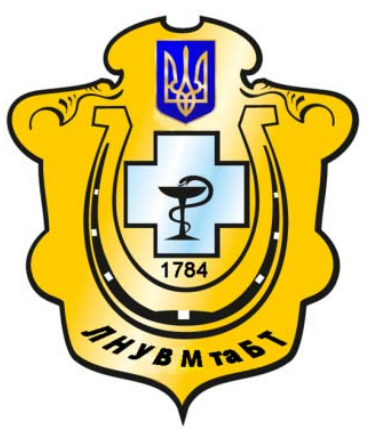

Науковий вісник Львівського національного університету ветеринарної медицини та біотехнологій імені С.3. Гжицького

Scientific Messenger of Lviv National University of Veterinary Medicine and Biotechnologies named after S.Z. Gzhytskyj

doi:10.15421/nvlvet7048

ISSN 2413-5550 print

ISSN 2518-1327 online

$\underline{\text { http://nvlvet.com.ua/ }}$

УДК 577.112: 612.1:636.52/.58

\title{
Інтенсивність процесів ПОЛ у крові курчат-бройлерів на тлі вакцинації проти хвороби нюкасла та за дії вітамінів Е та С
}

\author{
Л.В. Романович ${ }^{1}$, Б.М. Куртяк ${ }^{1}$, М.С. Романович ${ }^{1}$, Д.І. Мудрак ${ }^{2}$ \\ kurtakbohdan@gmail.com
}
${ }^{1}$ Львівський національний університет ветеринарної медицини та біотехнологій імені С. 3. Гжицького, вул. Пекарська 50, м. Львів, 79010, Україна;
${ }^{2}$ Інститут біології тварин НААН, вул. Василя Стуса, 38, м. Львів, 79000, Украӥна

\begin{abstract}
У статті наведені дані щзодо дослідження показників пероксидного окиснення ліпідів (ТБК-активних продуктів і гідроперекисів ліпідів) у крові курчат-бройлерів на тлі вакцинаиії проти хвороби Нюкасла та за дії вітамінів Е та С.

Дослідження проведено на трьох групах курчат по 100 птахів у кожній. Контрольній групі курчат згодовували стандартний комбікорм. Перша дослідна група птахів додатково до вказаного комбікорму отримувала - токоферол ацетат у кількості 0,1 г/кг комбікорму, друга - аскорбінову кислоту 0,25 г/кг комбікорму. Третя дослідна група курчат - токоферол ацетат і аскорбінову кислоту у вказаних дозах. Для досліджень використовували кров, яку брали в курчат після декапітаціі у різні вікові періоди: 11-, 27-, 34- і 41-добовому вічі. Результати показників різних вікових груп курчат-бройлерів порівнювали із величинами показників птиці 11-добового віку до вакиинації, і до контрольної групи птиці.

Проведені дослідження показали, щуо вміст проміжних і кінцевих продуктів ПОЛ у плазмі крові курчат-бройлерів залежить від віку та періоду імунізащії. Згодовування підвищених кількостей вітаміну Е та С у складі комбікорму для курчат-бройлерів спричинило зменшення ( $p<0,05$ - 0,001) вмісту у плазмі крові гідроперекисів ліпідів і ТБК-активних продуктів. Вірогідно нижчі показники ПОЛ у курчат-бройлерів дослідних груп свідчать про зменшення негативного впливу стрес-факторів на їх організм на тлі вакиинації їх проти хвороби Нюкасла. Ці зміни були виражені більшою мірою у крові курчат, які додатково до основного раціону отримували токоферол ачетат і аскорбінову кислоту.

Ключові слова: кури-бройлери, кров, токоферол ацетат, аскорбінова кислота, продукти перекисного окиснення ліпідів, система антиоксидантного захисту.
\end{abstract}

\section{Интенсивность процесса ПОЛ в крови цыплят-бройлеров на фоне вакцинации против болезни нюкасла и за действия витамин Е и С}

\author{
Л.В. Романович ${ }^{1}$, Б.М. Куртяк ${ }^{1}$, М.С. Романович ${ }^{1}$, Д.И. Мудрак ${ }^{2}$ \\ kurtakbohdan@gmail.com
}

\footnotetext{
${ }^{1}$ Львовский национальный университет ветеринарной медицины и биотехнологий имени С.3. Гжицкого, ул. Пекарская, 50, г. Львов, 79010, Украина,

${ }^{2}$ Институт биологии животных НААН, ул. Василия Стуса, 38, г. Львов, 79000, Украина
}

\begin{abstract}
В статье приведены данные по исследованию показателей перекисного окисления липидов (ТБК-активных продуктов и гидроперекисей липидов) в крови цыплят-бройлеров на фоне вакиинации против болезни Нюкасла и за действия витаминов Е и С. Исследование проведено на трех группах иыплят по 100 птии в каждой. Контрольной группе иылплят скармливали стандартный комбикорм. Первая опытная группа птии дополнительно к указанному комбикорма получала - токоферол аиетат в количестве 0,1 г/кг комбикорма, вторая - аскорбиновую кислоту 0,25 г/кг комбикорма. Третья исследовательская
\end{abstract}

\section{Citation:}

Romanovich, L.V., Kurtyak, B.M., Romanovich, M.S., Mudrak, D.I. (2016). Intensity of peroxidation in blood broiler vaccination against disease and under nyukasla vitamin E and C. Scientific Messenger LNUVMBT named after S.Z. Gzhytskyj, 18, 3(70), 200-203. 
группа иыплят - токоферол ачетат и аскорбиновую кислоту в указанных дозах. Для исследований использовали кровь, которую брали у ицыплят после декапитации в разные возрастные периоды: 11-, 27-, 34- и 41-суточном возрасте. Результаты показателей различных возрастных групп ияыплят-бройлеров сравнивали с величинами показателей птиць 11суточного возраста до вакичнации, и в контрольную группу птицьь.

Проведенные исследования показали, что содержание промежуточных и конечных продуктов ПОЛ в плазме крови ијыплят-бройлеров зависит от возраста и периода иммунизации. Скармливания повыменных количеств витамина Е и С в составе комбикорма для цзыплят-бройлеров привело к уменьшению (р <0,05 - 0,001) содержания в плазме крови гидроперекисей липидов и ТБК-активных продуктов. Вероятно низкие показатели ПОЛ у изыплят-бройлеров опьтных групп свидетельствуют об уменьшении негативного влияния стресс-факторов на их организм на фоне вакцинации их против болезни Нюкасла. Эти изменения были выражены в большей степени в крови цыьлят, дополнительно к основному рациону получали токоферол ачетат и аскорбиновую кислоту.

Ключевые слова: куры-бройлеры, кровь, токоферол ацетат, аскорбиновая кислота, продукты перекисного окисления липидов, система антиоксидантной зашитьл.

\title{
Intensity of peroxidation in blood broiler vaccination against disease and un- der nyukasla vitamin $\mathbf{E}$ and $\mathrm{C}$
}

\author{
L.V. Romanovich ${ }^{1}$, B.M. Kurtyak ${ }^{1}$, M.S. Romanovich ${ }^{1}$, D.I. Mudrak ${ }^{2}$ \\ kurtakbohdan@gmail.com \\ ${ }^{1}$ Lviv national university of veterinary medicine and biotechnologies named after S. Gzhytskyj, \\ Pekarska Str., 50, Lviv, 79010, Ukraine; \\ ${ }^{2}$ Institute of animal biology NAAS, \\ Vasyl Stus Str., 38, Lviv, 79000, Ukraine
}

\begin{abstract}
The article presents research data on indices of lipid peroxidation (TBA-active products and hydroperoxides lipids) in the blood of broiler chickens on the background of vaccination and disease Nyukasla for the actions of vitamins $E$ and $C$.

The study was conducted on three groups of 100 broiler birds each. Control group fed normal chicken feed. The first research group in addition to poultry feed said received - tocopherol acetate in an amount of $0.1 \mathrm{~g} / \mathrm{kg}$ feed, the second - ascorbic acid $0.25 \mathrm{~g} / \mathrm{kg}$ feed. The third research group chickens - tocopherol acetate and ascorbic acid at these doses. For research use blood that was in the chicken after decapitation at different ages: 11-, 27-, 34- and 41-day age. The results of performance of different age groups broiler chickens compared with the value of the index poultry 11-day age for vaccination, and a control group of birds.

Studies have shown that the content of intermediate and final products of lipid peroxidation in the blood plasma of broilers depends on the age and period of immunization. Feeding high amounts of vitamin $E$ and $C$ in the composition of feed for broiler chickens caused a reduction $(p<0.05-0.001)$ content in plasma lipid hydroperoxides and TBA-active products. PAUL likely lower rates of broiler chickens research groups suggest reducing the negative impact of stress factors on their bodies on the background of vaccination against the disease Nyukasla. These changes were more pronounced in the blood of chickens, which in addition to the basic diet receiving tocopherol acetate and ascorbic acid.
\end{abstract}

Key words: chickens, broilers, blood, tocopherol acetate, ascorbic acid, products of lipid peroxidation, antioxidant protection.

\section{Вступ}

Сучасні методи ведення промислового птахівництва передбачають інтенсивні технології, які не завжди відповідають фізіологічним особливостям різних видів птиці. Тому однією з найбільших проблем, що існує у галузі птахівництва, є зниження життєздатності птахів, особливо у ранньому віці. Наявність вікової динаміки та критичних періодів у становленні імунобіологічної реактивності у постнатальний період розвитку та дія антропогенних чинників дестабілізують метаболічні процеси в організмі птиці, призводять до зниження природної резистентності, імунодефіциту і в окремих випадках - до загибелі (Vladimirov et al., 1994; Vlizlo et al., 2015).

Резистентність птиці до інфекційних захворювань залежить від функціонального стану органів системи імунітету. Серед збудників хвороб птиці, що особливо уражують імунну систему це віруси інфекційного бронхіту, ньюкаслської хвороби та вірусної бурсальної хвороби (хвороба Гамборо). Вони проявляють тропізм до лімфоїдних клітин, викликають їх руйнування і блокують імунну відповідь птиці (Sies, 1993; Suraj et al., 1997). В останні роки запропоновано цілу низку препаратів, що стимулюють імунітет (імуностимулятори, імуномодулятори), водночас, будьякий препарат, вибірково діючий на імунну систему, може згубно впливати на організм.

Для підвищення адаптаційної здатності й імунобіологічної реактивності організму у птиці в останні роки 3 успіхом використовують вітаміни. Зокрема, окремими авторами встановлено стимулювальний вплив вітамінів Е і C на активність імунної та антиоксидантної системи, продуктивність і збереженість у курей (Surai et al., 1998; Simonov, 2007).

Велика кількість досліджень свідчить про зв'язок вітаміну C та Е з імунною реакцією організму (Ionov et al., 1992; Noblet et al., 1993). Вітамін С безпосередньо впливає на структуру та функцію імунокомпетентних клітин, і тим самим «розвантажує» імунну систему (Surai and Sparks, 2001). Аскорбінова кислота впливає переважно на неспецифічну ланку імунітету, підвищуючи синтез макрофагальних білків, білків системи комплементу, і таким чином посилює неспецифічну резистентність організму та противірусний імунітет (Wang and Erf, 2004). Вітамін C не тільки безпосередньо вбиває бактерії і допомагає нейтралізувати бактеріальні токсини, а також активує природ- 
ні захисні механізми. Аскорбінова кислота вмонтовується безпосередньо в біологічні мембрани та ефективно захищає їх від пероксидного окиснення ліпідів, i підтримує майже всі клітини імунної системи, особливо антитіла та білі клітини крові, які втрачають вітамін С під час хвороби. Комплексне використання аскорбінової кислоти і вітаміну Е $\epsilon$ ще ефективнішим засобом у захисті поліненасичених жирних кислот (ПНЖК) мембран від пероксидного окиснення (Puthpongsiriporn et al., 2001; Baglaj et al., 2011; Gutyj, 2013).

3 даних літератури відомо, що інтенсивність процесів ПОЛ $є$ тісно пов'язана з напруженістю імунітету (Simonov, 2007).

Наведене вище обгрунтовує доцільність дослідження впливу додаткового введення до раціону курчат-бройлерів у ранньому віці вітамінів Е і С на інтенсивність процесів пероксидного окиснення ліпідів на тлі вакцинації їх проти хвороби Нюкасла, що було і метою нашої роботи.

\section{Матеріал і методи досліджень}

Дослідження проводили у фермерському господарстві «Федюк М» села Новосілки Золочівського району Львівської області на чотирьох групах курчатбройлерах по 100 голів у кожній, починаючи з 1- до 45-добового віку. Утримання курчат було клітковим 3 вільним доступом до корму і води. Контрольній групі курчат згодовували стандартний комбікорм, збалансований за основними поживними речовинами згідно норм рекомендованих для кросу РОСС - 308 та у 13добовому віці випоювали вакцину проти хвороби Нюкасла Lasota Forte. Перша дослідна група птахів додатково до вказаного комбікорму отримувала токоферол ацетат у кількості 0,1 г/кг комбікорму, друга - аскорбінову кислоту 0,25 г/кг комбікорму. Третя дослідна група курчат - токоферол ацетат i аскорбінову кислоту у вказаних дозах.

Для досліджень використовували кров, яку брали в курчат після декапітації у різні вікові періоди: 11-, 27-, 34- і 41-добовому віці. Під час виконання роботи дотримувались біоетичних вимог, щодо тварин згідно чинного законодавства. Результати показників різних вікових груп курчат-бройлерів порівнювали із величинами показників птиці 11-добового віку до вакцинації, і до контрольної групи птиці.

У плазмі крові визначали вміст гідроперикисів ліпідів (ГПЛ; Мирончик А. К., 1982) і ТБК-активні продукти (Коробейникова Е. Н., 1989).

Одержані цифрові дані опрацьовано статистично 3 використанням програмного пакету Microsoft Excel для персональних комп'ютерів, за допомогою загальноприйнятих методів варіаційної статистики 3 визначенням середніх величин (M), їх квадратичної похибки (m) та достовірності різниць, які встановлювали за $\mathrm{t}-$ критерієм Стьюдента.

\section{Результати та їх обговорення}

Відомо, що проміжним етапом окиснення наявних у ліпідах поліненасичених жирних кислот пероксид- ним шляхом $є$ утворення гідроперекисів ліпідів, 3 якими значною мірою пов'язана деструктивна дія продуктів ПОЛ у клітині (Vladimirov et al., 1994). 3 наведених у таблиці даних бачимо, що вміст проміжних продуктів ПОЛ у плазмі крові курчат бройлерів контрольної групи у 27-, 34- і 41-добовому віці був відповідно на 20,6; 23,5 і 35,3\% (p < 0,001) більший, ніж у 11-добовому віці, до введення вакцини. При цьому у плазмі крові курчат бройлерів у вказані періоди досліджень зафіксовано зростання вмісту ТБКактивних продуктів, проте різниці порівняно до контролю були не вірогідні. Одержані результати досліджень свідчать про зростання інтенсивності процесів ПОЛ у крові птиці з віком та проведеною імунізацією. Це пояснюється тим, що в біохімічних механізмах, які лежать в основі росту і розвитку курчат у ранньому віці, важливу роль відіграють вільнорадикальні процеси (Sies, 1993). Водночас, як вже зазначалося (Simonov, 2007) інтенсивність процесів ПОЛ є у корелятивній залежності 3 напруженістю імунітету. Як показали проведені дослідження, найбільш інтенсивне зростання процесів пероксидного окиснення ліпідів зафіксовано в організмі курчат у період активного росту.

Отже, у процесі росту проходить інтенсивне окиснення наявних у ліпідах поліненасичених жирних кислот пероксидним шляхом. Додаткове введення до раціону курчат-бройлерів вітамінів Е і С спричиняло інгібуючий вплив на інтенсивність процесів пероксидного окиснення ліпідів у плазмі крові. Так, концентрація гідроперекисів ліпідів, які є проміжними продуктами ПОЛ, у плазмі крові курчат-бройлерів дослідних груп на всіх стадіях дослідження була менша $(\mathrm{p}<0,05-0,001)$, ніж у контрольній (табл. 1). Вказані зміни були виражені більшою мірою у крові курчатбройлерів, які додатково до основного раціону отримували вітаміни Е і С.

Гідроперекиси ліпідів $\epsilon$ проміжним етапом окиснення наявних у ліпідах поліненасичених жирних кислот до малонового діальдегіду. Різниці в концентрації ТБК-активних продуктів у плазмі крові курчатбройлерів дослідних груп порівняно до контрольної були подібні до різниць у вмісті гідроперекисів ліпідів. Вміст у плазмі крові ТБК-активних продуктів, які утворюються в результаті розриву поліненасичених жирних кислот, обумовленого вільними радикалами, відображає активність процесів ПОЛ в організмі і слугує маркером ступеня ендогенної інтоксикації. Індикатором посилення перебігу процесів ПОЛ у організмі є збільшення вмісту хоча б одного із його продуктів (Vladimirov et al., 1994). Визначення вмісту продуктів ПОЛ у крові курчат-бройлерів до певної міри характеризує перебіг окисно-відновних процесів та активність антиоксидантної системи в цілому. Отриманий менший ( $<<0,05-0,001)$ вміст ТБКактивних продуктів у плазмі крові курчат після застосування вітамінів Е і C, порівняно 3 контролем, може свідчити про вищу функціональну активність системи антиоксидантного захисту та кращу опірність організму птиці до дії стресових факторів. 


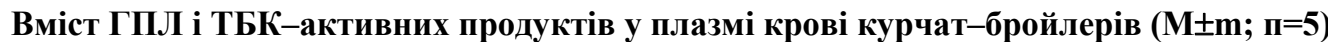

\begin{tabular}{|c|c|c|c|c|c|}
\hline \multirow{2}{*}{ Показники } & Гру & \multicolumn{4}{|c|}{ Вік курей, діб } \\
\cline { 3 - 6 } & пи & 11 & 27 & 34 & 41 \\
\hline \multirow{3}{*}{ ГПЛ, од. Е/мл } & $\mathrm{K}$ & $0,34 \pm 0,01$ & $0,41 \pm 0,007^{\text {ооо }}$ & $0,42 \pm 0,007^{\text {о0о }}$ & $0,46 \pm 0,008^{\text {ооо }}$ \\
\cline { 2 - 6 } & $Д_{1}$ & $0,33 \pm 0,004$ & $0,36 \pm 0,005^{* * *}$ & $0,39 \pm 0,007^{*}$ & $0,42 \pm 0,009^{* *}$ \\
\cline { 2 - 6 } & $Д_{2}$ & $0,33 \pm 0,007$ & $0,36 \pm 0,005^{* * *}$ & $0,38 \pm 0,004^{* *}$ & $0,41 \pm 0,008^{* *}$ \\
\cline { 2 - 6 } & $Д_{3}$ & $0,31 \pm 0,009$ & $0,34 \pm 0,006^{* * *}$ & $0,36 \pm 0,009^{* * *}$ & $0,36 \pm 0,007^{* * *}$ \\
\hline \multirow{3}{*}{ МДА, мкмоль/мл } & $\mathrm{K}$ & $1,72 \pm 0,01$ & $1,84 \pm 0,025$ & $2,01 \pm 0,013$ & $2,28 \pm 0,090$ \\
\cline { 2 - 6 } & $Д_{1}$ & $1,69 \pm 0,01$ & $1,63 \pm 0,014$ & $1,84 \pm 0,067^{*}$ & $2,03 \pm 0,066$ \\
\cline { 2 - 6 } & $Д_{2}$ & $1,64 \pm 0,03$ & $1,55 \pm 0,052^{* *}$ & $1,87 \pm 0,068$ & $2,0 \pm 0,093$ \\
\cline { 2 - 6 } & $Д_{3}$ & $1,61 \pm 0,04^{*}$ & $1,54 \pm 0,051^{* * *}$ & $1,56 \pm 0,052^{* * *}$ & $1,62 \pm 0,079^{* * *}$ \\
\hline
\end{tabular}

Примітка. У цій таблиці різниці статистично вірогідні порівняно 3 контролем: * $-\mathrm{p}<0,05 ; * *-\mathrm{p}<0,01 ; * * *-\mathrm{p}<0,001$; вірогідність різниць до періоду вакцинації

Отже, отримані результати щодо впливу вітамінів Е і C на вміст продуктів ПОЛ у крові, свідчать про їх позитивний вплив на організм курчат. Після застосування досліджуваних вітамінів курчатам-бройлерам дослідних груп ми отримали вірогідно нижчі показники вмісту гідроперекисів ліпідів та ТБК-активних продуктів у плазмі крові птиці. 3 огляду на це можна зробити висновок, що вміст проміжних та кінцевих продуктів ПОЛ залежить від віку, активності антиоксидантної системи, приростів живої маси та впливу стресових факторів на організм курчат. Застосовані вітаміни Е і C для курчат дослідних груп показали їх адаптогенні властивості, оскільки підвищення активності процесів вільнорадикального окиснення у фізіологічних умовах розглядається як адаптаційна реакція організму на дію стресових факторів. Вірогідно нижчі показники ПОЛ у курчат-бройлерів дослідних груп свідчать про зменшення негативного впливу стрес-факторів на їх організм на тлі вакцинації їх проти хвороби Нюкасла.

\section{Висновки}

Констатовано, що вміст проміжних і кінцевих продуктів ПОЛ у плазмі крові курчат-бройлерів залежить від віку та періоду імунізації. Застосування у складі раціону для курчат-бройлерів підвищених кількостей вітаміну $\mathrm{E}$ та С спричинило зменшення $(\mathrm{p}<0,05-0,001)$ вмісту у плазмі крові гідроперекисів ліпідів і ТБК-активних продуктів. Ці зміни були виражені більшою мірою у крові курчат-бройлерів, які додатково до основного раціону отримували токоферол і аскорбінову кислоту.

\section{Бібліографічні посилання}

Vlizlo, V.V., Kurtjak, B.M., Vudmaska, I.V., Vishhur, O.I., Petruk. A.P. (2015). Zhyrorozchynni vitaminy u veterynarnij medycyni ta tvarynnyctvi: monogr. 2-ge vyd., dopov. i pererob. L'viv. Spolom (in Ukrainian).

Vladimirov, Ju.A., Azizova, O.A., Deev, A.I. (1994). Svobodnye radikaly $\mathrm{v}$ zhivyh sistemah. Itogi nauki $\mathrm{i}$ tehniki. Biofizika. 29, 3, 250 (in Ukrainian).

Sies, H. (1993). Strategies of antioxidant defense. Eur. J. Biochem. 215, 2, 213-219.
Suraj, P.F., Buzhin, A.A., Jaroshenko, F.A., Ionov, I.A. (1997). Zhirorastvorimye vitaminy. Cherkassy (in Ukrainian).

Surai, P., Kostjuk, I., Wishart, G. et al. (1998). Effect of vitamin $\mathrm{E}$ and selenium supplementation of cockerel diets on glutathione peroxidase activity and lipid peroxidation susceptibility in sperm, testes and liver. Biol. Trace Elem. Res. 64, 1-3, 119-132.

Simonov, M.R. (2007). Vikovi osoblyvosti formuvannja imunitetu proty hvoroby Gamboro $\mathrm{i}$ antyoksydantnogo statusu ta metody i'h korekcii' u kurej krosu ISA BROWN: avtoref. dys. na zdobuttja nauk. stupenja kand. vet. nauk: spec. 03.00.04 «Biohimija». L'viv, 16 (in Ukrainian).

Ionov, I.A., Suraj, P.F., Kuchmistov, V.O. (1992). Vmist vitaminiv A i E v pechinci gusej $\mathrm{v}$ embriogenezi ta rann'omu vici. Ukr. konf. molodyh vchenyh ta aspirantiv z pytan' ptahivnyctva. Harkiv, 24-25 (in Ukrainian).

Baglaj, O.M., Murs'ka, S. D., Gutyj, B.V., Gufrij, D.F. (2011). Systema antyoksydantnogo zahystu ta perekysne okysnennja lipidiv organizmu tvaryn. Naukovyj visnyk L'vivs'kogo nacional'nogo universytetu veterynarnoi' medycyny ta biotehnologij im. G'zhyc'kogo. 13, 4(2), 3-11 (in Ukrainian).

Gutyj, B.V. (2013). Vplyv E-selenu na vmist vitaminiv A i E u krovi bychkiv za umov kadmijevoi' intoksykacii'. Naukovyj visnyk L'vivs'kogo nacional'nogo universytetu veterynarnoi' medycyny ta biotehnologij im. G'zhyc'kogo. 15, 3(3), 311-314 (in Ukrainian).

Noblet, R.C., Cocchi, M., Bath, H.M. (1993). a-tocopherol absorption and polyunsaturated fatty acid metabolism in the developing chick embryo // British Poultry Sci. 34, 815-818.

Surai, P.F., Sparks, N.H. (2001). Comparative evaluation of the effect of two maternal diets on fatty acids, vitamin $\mathrm{E}$ and caratenoids in the chick embryo. Br. Poult. Sci. 42, 2, 252-259.

Wang, X., Erf, G.F. (2004). Melanocyte-specific cell mediated immune response in vitiliginous Smyth line chickens. J. Autoimmun. 21, 149-160.

Puthpongsiriporn, U., Schiedeler, S., Sell, J. et al. (2001). Effects of vitamins $\mathrm{E}$ and $\mathrm{C}$ supplementation on performance in vitro lymphocyte proliferation and antioxidant status of laying hens during heat stress. Poult. Sci. 80, 1190-2000. 